\title{
VHF 海洋レーダの表層流観測による潮目挙動の解析
}

\author{
徳田正幸* ・寺内潔** - 村崎定男 ${ }^{* * *}$ \\ 村嶋陽一****. 金津伸好 $* * * * *$
}

\section{1.はじめに}

海上のごみ回収作業の効率化を計るためには，図一1 に示したように, 次の 2 つ課題を改善する必要がある. 第 1 はごみの分布の正確な情報（ごみの初期分布）であ る. 第 2 はごみの浮遊移動の予測精度の向上である. 海 上のごみは一般に潮目に集まると言われている，湾内で ごみを集める潮目は規模が大きく持続性の高いもので, 主に潮汐フロントによって出来る潮目と考えられる. 本 研究の目的は, VHF 海洋レーダによる表層流観測と潮 目の目視観測を同時に行い, これらの観測からごみを集 める潮目の挙動特性を解明し, 上記の第 2 の課題の予測 精度の向上（図一1の(3)〜(5)）を図ることにある.

\section{2. レーダ観測}

使用したレーダは徳田ら (1997)（以後流れ観測論文と 呼ぶ）が開発したVHF 海洋レーダである。

\section{1 観 測 法}

図一2において,レーダ局として A 局と B 局そしてア ンテナビーム及び観測領域 (ハッチ状の領域)を示した. 本論文で解析したレーダ観測デー夕は, 海域特性を調べ るための 15 日間 (1998 年 8 月 31 日〜 9 月 14 日) と, 潮 目の目視観測を行った 10 月 9 日のものである.今回の流 れの観測方法は流れ観測の論文と同じで，1ビーム当た り約 5 分間の照射観測で，観測周期は 1 時間となる.

\section{2 解 析 法}

本節で述べる解析法は, 流れ観測論文で使用した方法 を発展させたものである.

1）ドップラスペクトルピーク周波数抽出法

表層流は徳田・永松（1999）で詳しく示されているよ うに,ドップラスペクトルピーク周波数から求められる. 今回の観測領域 (図一2)においては照射したレーダビー ムが対岸に当たる場合があり,このような場合多重反射 の危険性がある. 図一 3 はあるビームで観測された,レン

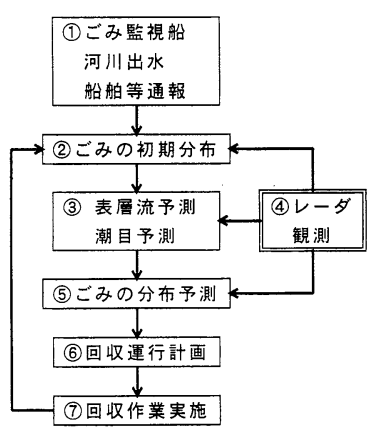

図一1 ごみ回収作業フロー図

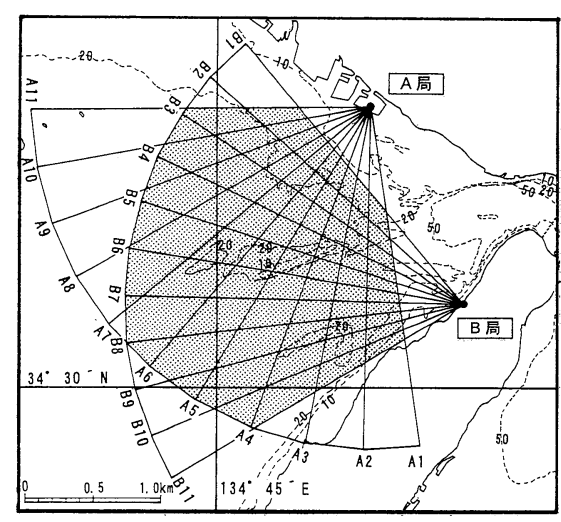

図一2 VHF 海洋レーダの観測海域

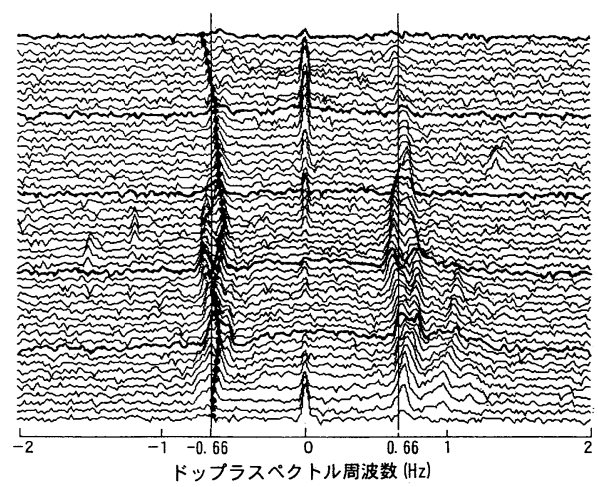

図-3 ドップラスペクトルピーク周波数のレンジ分布 


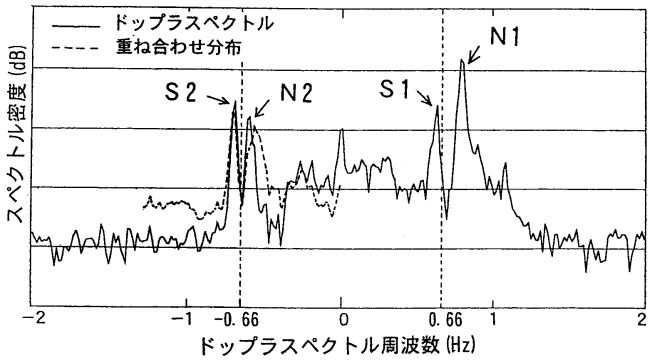

図-4 ドップラスペクトルピーク周波数抽出法
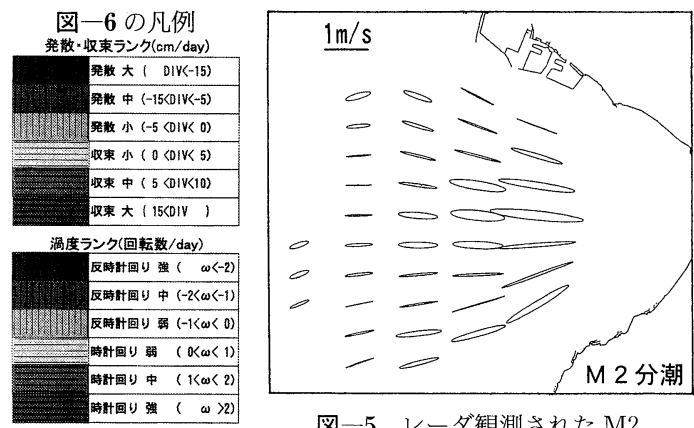

図一5 レーダ観測された M2 分潮流場特性

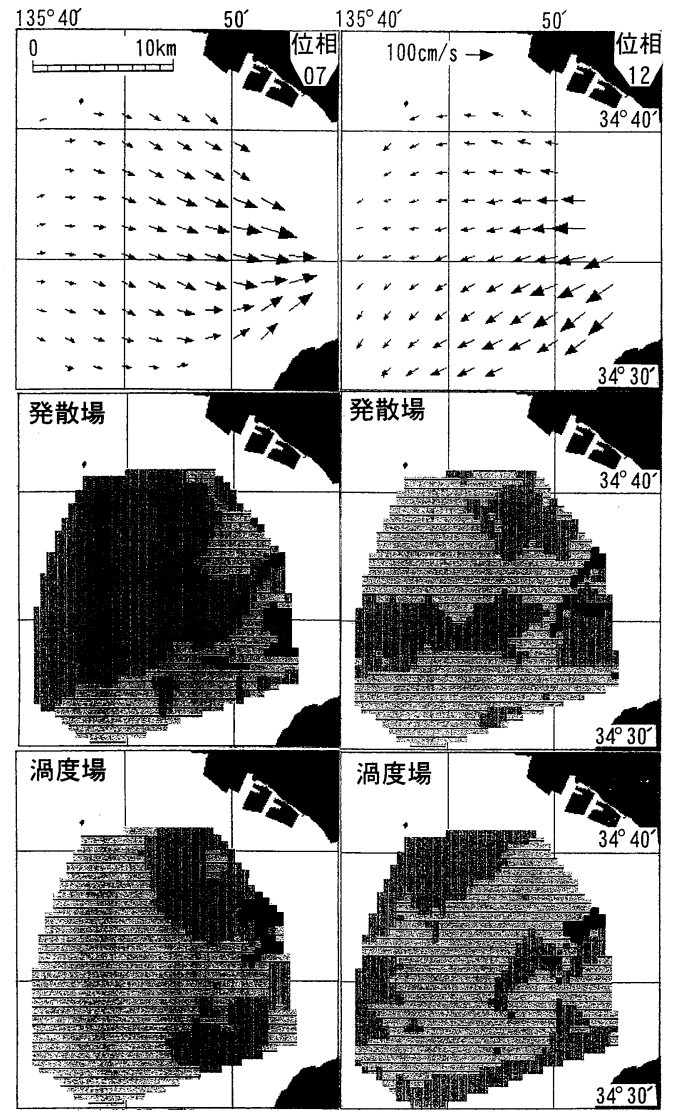

図一6 レーダ観測された流れ場特性
ジ方向 $0.5 \mathrm{~km}$ 毎のドップラスペクトルを原点をずらし て図示したものである.この図から分かるように，レン ジ距離 5〜15 km にわたって，2つ山ピークの分布が見 られる. 図-4 は図-3 のレンジ距離 $9 \mathrm{~km}$ のスペクトル を取り出したものである。この図で見られるように，多 重反射による異常ピーク（N1 と N2）はブラッグ共鳴第 1 次散乱より大きくなることがある. 異常なピークの検 出において，私たちの今までのアルゴリズムではあるレ ンジ距離のみであれば可能であるが，レンジ距離に対し て連続的に異常ピークの出現に対しては不可能となる. このために, ブラッグ共鳴の特性である, 2 つの第 1 次 散乱ピークはゼロ表層流の周波数 $( \pm 0.66 \mathrm{~Hz})$ に対して 平行移動する特性を利用するアルゴリズムを考案した。 すなわち，正と負の周波数領域のスペクトルをいずれか にゼロ表層流の周波数だけ移動して，2つのスペクトル の合成を行えば，求めたいブラッグ共鳴のピークは強め 合うが，多重反射による偽りのピークは逆に弱め合うこ とになる. 図-4の点線のスペクトルが上記の考えで合 成されたスペクトルで, 求めたいブラッグ共鳴のピーク がノイズのピークより大きくなり，正常に抽出できるこ とになる。

2) 潮流特性解析法

次の点を除いて, 流れ観測論文の図一11 と同じ解析を する. 本論文では周期変動の基準として明石の予測潮流 の最強西流を用いたこと.すなわち, ある最強西流時か ら次の最強西流間を 1 周期と区分した. 各区分の位相分 割数を 12 個としたことである.

3）発散と渦度の計算法

レーダは面的に表層流を観測し，その観測值を空間分 解能 $\Delta s=0.5 \mathrm{~km}$ の格子点上で表すことができるので, 1 時間毎に潮目の挙動に関係する発散と渦度の分布を解 析することが出来る。ここで格子点 $(i, j)$ の $X$ 軸方向と $Y$ 軸方向の流速を $u_{i j}$ と $v_{i j}$ とする. 発散 DIV と渦度 $\omega$ は次式で定義した。

$$
\begin{aligned}
& D I V=\frac{A}{2 \Delta s}\left(-u_{i+1, j}+u_{i-1, j}-v_{i, j+1}+v_{i, j-1}\right) \\
& \omega=\frac{A}{2 \Delta s}\left(u_{i, j+1}-u_{i, j-1}-v_{i+1, j}+v_{i-1, j}\right) \cdots \cdots \cdots
\end{aligned}
$$

これらは空間的単位として中央差分の $2 \Delta s$ で表現し, 時 間的単位としては 1 日分の変化量とした.これらの強度 は図一6の凡例で示したように，6段階に分類し，それぞ れの特性分布を示した。 これらの分布は短時間の変動を 消去するために 3 時間の移動平均を行った. 後述する潮 目の観測は約 20 分間毎に行った.これらの観測データと 同期させる特性分布は，上記の移動平均した 1 時間毎の 分布から，時間的に補間して求めた。 


\section{3 海 域 特 性}

図一2で示した観測海域の特性はすでに述べた 15 日 間のレーダ観測データから議論する. 図 $\mathbf{5}$ は調和解析 法で解析された $M 2$ 分潮の潮流成分の結果である.図一 6 は発散・渦度解析と潮流特性解析から得られたもので, 最強の西流時と東流時の位相時の分布を代表的に示した ものである。これらの結果から次のことが言える.

1）播磨灘の東海域は潮流が卓越し，とくにM2 分潮 成分が明石海峡に近づけば近づくほど強くなり, 流向は ほぼ東西方向となる。

2）発散場において，全体的にあまり特徴は見られな いが, 明石海峡に近い海域において, 最強の東流では収 束 (堆積で水位上昇) 海域が, 最強の西流では発散（水 位下降）海域が卓越する。

3）渦度分布において, 強い時計回りと強い反時計回 りの強い境界はとくに明石海峡に近い大きな流速域に存 在する.また，比較的に弱い境界は沿岸域にあり， とくに淡路島沿岸域に系統的に見られる. 後述す るように，ごみを集める潮目はマクロ的には発散 場よりも渦度場に強く関係する。

\section{3. 潮流数値計算}

湾内の浮遊物（ごみ, 油等）の従来の移動予測 は通常非定常な潮流数值計算の表層流に基づいて いる.よって, レーダ観測值と潮流の数值計算值 の比較を行い,レーダ観測の有用性を明らかにす る必要がある。比較は主に発散場, 渦度場及び潮 目の挙動で行う。

使用した潮流数值計算の概略は徳田ら（1993） と同じ内容で, 1 層モデルとし，コリオリ係数 0.00082 , 水平渦動粘性係数 $5.0 \mathrm{~m}^{2} / \mathrm{s}$ とした. 計算 条件は次の通りである。

\section{（1）計算範囲と格子}

計算範囲は図一7で示した範囲で，レーダ観測 との比較は, この図の $\mathrm{A}$ の部分を切り出し使用し た。格子間隔とタイムステップはそれぞれ $1 \mathrm{~km}$ と 15 秒とした.

\section{（2）初期条件と境界条件}

初期条件は必要とする結果の 2 日前で, すべて の格子点で静止状態の条件とした，境界条件は外

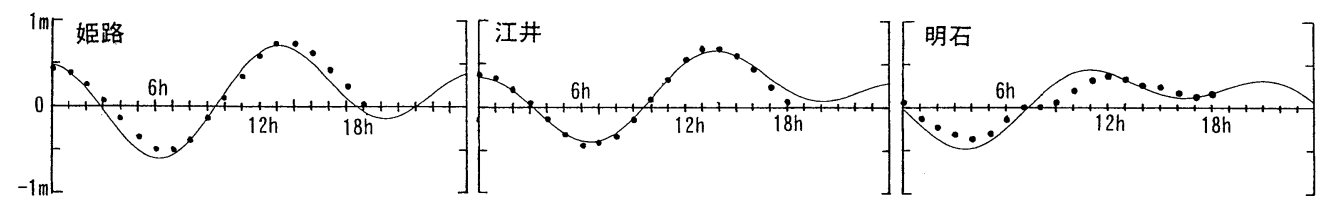

図一 8 数值計算された潮位特性
力である潮位変化 (16 成分の調和定数を使用)を図一7の 西側と南側の境界で与えた。

\section{（3）潮目の挙動の数値計算}

潮目の形状を粒子群で近似し，2つの流れ場を基に 60 秒毎にその移動計算を行った。使用した流れ場はレーダ

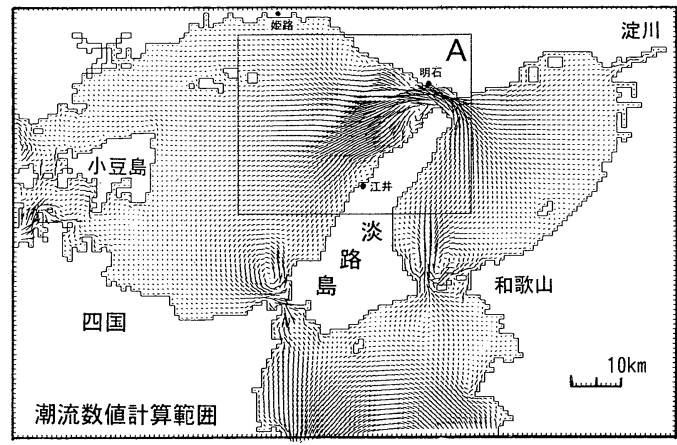

园一7 潮流数值計算範囲

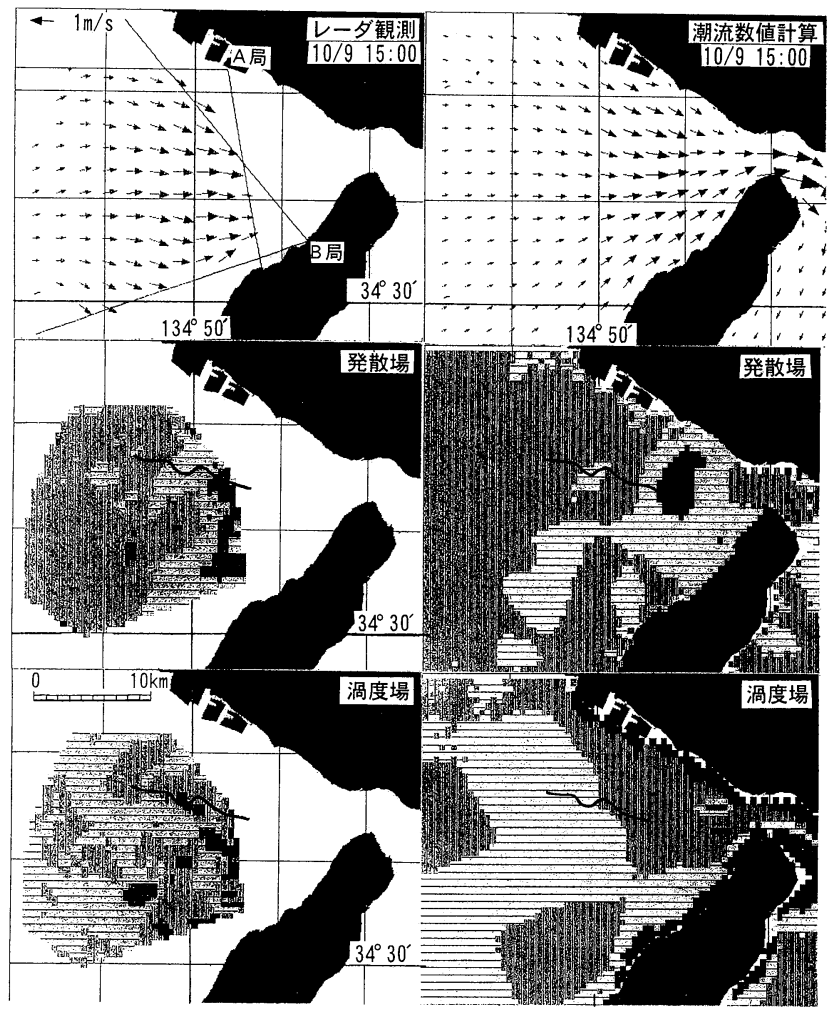

図一9 レーダ観測と数值計算の流れ場の比較

\section{1}


で観測された場と潮流計算された場（1 時間毎）を基に 60 秒毎の内挿計算で求めた。粒子はこらの流れ場の 0.7 の移動速度で移動すると仮定した。

使用した数值計算の精度の検証は計算範囲内の代表的 な 3 点(姫路, 江井, 明石)の潮位で行い, 図一8を得た. この図において数值計算からの值（点）は予想潮位の值 (実線)とよく一致し, 数值計算の精度は十分であること が示された。

\section{4. レーダ観測と潮流数值計算の流れ場の相違}

両者の流れの比較は, 後述する潮目の目視観測期間 (1998 年 10 月 9 日 12 時〜 15 時)で行った. 図一 9 は最強 時の東流の代表的な流れ場の比較例を示した. 発散場と 渦度場の実線は, 観測された潮目を同時に示した。この 図から，次のことが言える。

（1）流れ場 (上図）: 両者は類似した流れパターンで あるが, 東経 134 度 45 分〜 50 分の海域において,レーダ 観測の方が全体的に大きい流速分布である.

（2）発散場(中図）：全体的に両者は類似した分布で ある. 明石海峡の手前の海域で, 数值計算場も強い収束 領域が存在する.しかしその位置は（1）と関連して数 值計算場の方が海峡により近い位置となる。

（3）渦度場(下図）：パターンは非常に異なる. 数值 計算場は岸に隣接した沿岸域以外に強い渦分布は存在し ないが, レーダ観測場は岸から十分に離れた海域で系統 的な渦度分布が存在する.

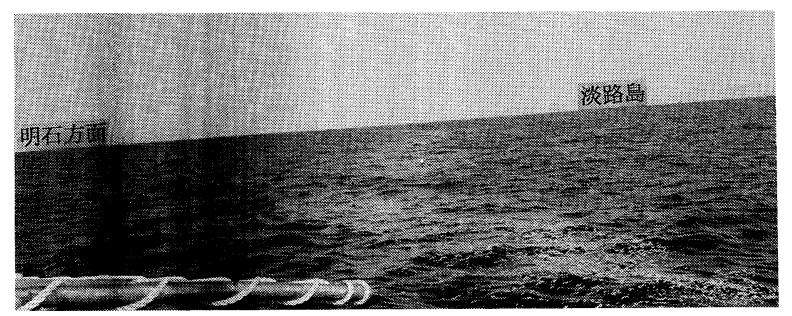

写真一1 目視観測された潮目

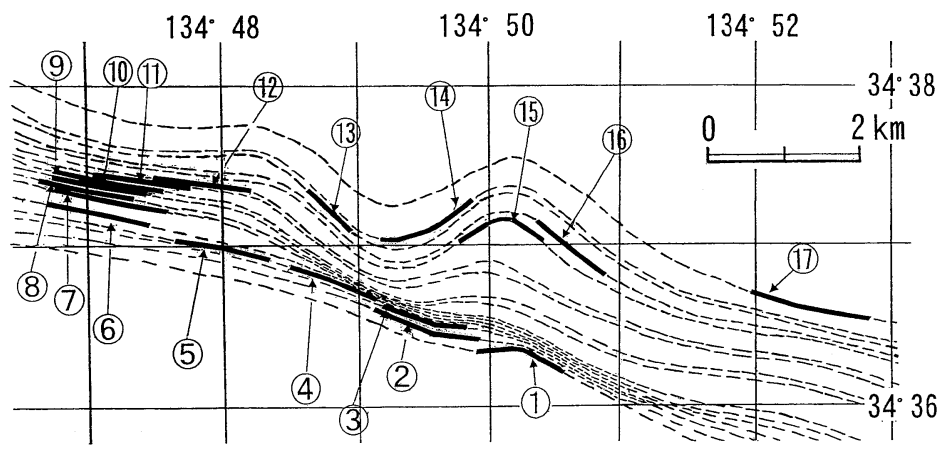

図一10 目視観測された潮目の挙動
以上のことにより，レーダ観測と潮流数值計算の流れ 場の大きな相違は, 渦度分布に見られる。

\section{5. 潮 目 観 測}

観測の目的はごみを集める潮目（写真一1）を目視観測 し，その特性を明らかにする。また，潮目移動デー夕は レーダ観測場と数值計算場の照合データに利用すること にある。潮目観測期間の流況ははじめに弱い西流期 $(12$ 時), 転流期 (13 時), 東流期（14 時以降）である. 東流 の最強時は 16 時である.

\section{1 観 測 法}

小型船で以下の観測を行った。ごみを集める潮目の目 視観測を行い, その位置は約 20 分毎に GPS で計測した. 潮目の特性を調べるために，木片を投下して潮目近辺の 流れ場の観測及び潮目を挾んで水塊の相違を調べる STD の観測を行った.また風向風速計による海上風の観 測を行ったが, 潮目観測期間中は最大風速が $3 \mathrm{~m} / \mathrm{s}$ 以下 で，ほとんど無風状態と言える。

\section{2 潮目の挙動}

図一10 と表一 1 が目視観測された潮目の挙動である. 潮目の東西方向の分布は，観測船が 1 隻であったために 十分観測できなかった. よって, 図一10の点線部分は推 定した形状である.この結果から，次のことが言える.

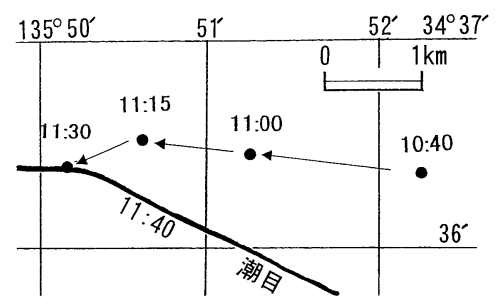

図一11 木片による潮目付近の流れ場

表一1 潮目の目視観測点の位置

\begin{tabular}{c|c|c|c}
\hline \multirow{2}{*}{ 観測 } & \multicolumn{3}{|c}{ 潮目の目視観測点の位置 } \\
\cline { 2 - 4 } (時刻 & 北緯 & 東経 \\
\hline (1) & $11: 30$ & $34^{\circ} 36.47^{\prime}$ & $134^{\circ} 50.24^{\prime}$ \\
\hline (2) & $11: 45$ & $34^{\circ} 36.49^{\prime}$ & $134^{\circ} 49.51^{\prime}$ \\
\hline (3) & $12: 00$ & $34^{\circ} 36.48^{\prime}$ & $134^{\circ} 49.84^{\prime}$ \\
\hline (4) & $12: 16$ & $34^{\circ} 36.86^{\prime}$ & $134^{\circ} 48.97^{\prime}$ \\
\hline (5) & $12: 18$ & $34^{\circ} 37.16^{\prime}$ & $134^{\circ} 48.00^{\prime}$ \\
\hline (6) & $12: 20$ & $34^{\circ} 37.37^{\prime}$ & $134^{\circ} 47.20^{\prime}$ \\
\hline (7) & $12: 30$ & $34^{\circ} 37.42^{\prime}$ & $134^{\circ} 47.23^{\prime}$ \\
\hline (8) & $13: 20$ & $34^{\circ} 37.53^{\prime}$ & $134^{\circ} 47.09^{\prime}$ \\
\hline (9) & $13: 30$ & $34^{\circ} 37.52^{\prime}$ & $134^{\circ} 47.14^{\prime}$ \\
\hline (1) & $13: 45$ & $34^{\circ} 37.52^{\prime}$ & $134^{\circ} 47.29^{\prime}$ \\
\hline (11) & $14: 00$ & $34^{\circ} 37.55^{\prime}$ & $134^{\circ} 47.47^{\prime}$ \\
\hline (12) & $14: 15$ & $34^{\circ} 37.48^{\prime}$ & $134^{\circ} 47.71^{\prime}$ \\
\hline (13) & $14: 36$ & $34^{\circ} 37.32^{\prime}$ & $134^{\circ} 48.79^{\prime}$ \\
\hline (14) & $15: 00$ & $34^{\circ} 37.14^{\prime}$ & $134^{\circ} 49.55^{\prime}$ \\
\hline (15) & $14: 26$ & $34^{\circ} 37.18^{\prime}$ & $134^{\circ} 50.04^{\prime}$ \\
\hline (16) & $14: 26$ & $34^{\circ} 37.02^{\prime}$ & $134^{\circ} 50.69^{\prime}$ \\
\hline (1) & $15: 35$ & $34^{\circ} 36.62^{\prime}$ & $134^{\circ} 52.37^{\prime}$ \\
\hline
\end{tabular}




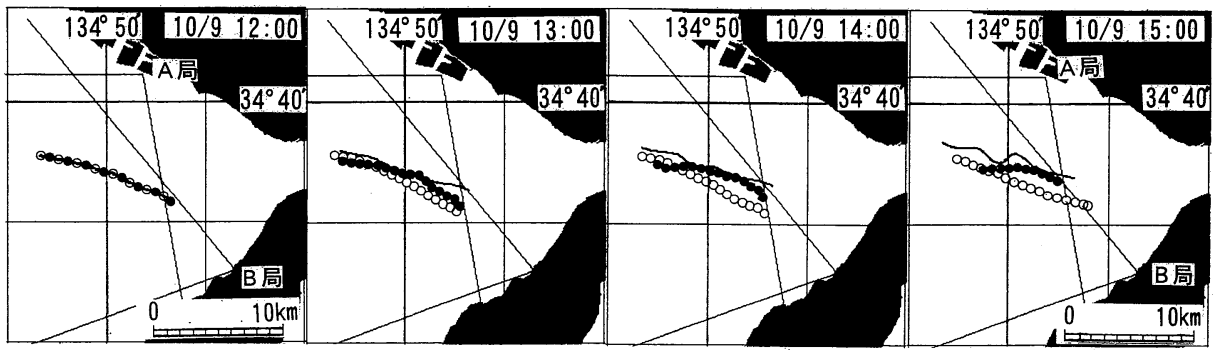

図一12 観測と数值計算の流れ場に対して潮目挙動の比較 - : 観測された潮目, ○：レーダ観測場，○：潮流数值計算場

（1）目視観測によれば, 潮目は時間とともに北上し， 転流時からごみを集める力が徐々に弱まった。東向きの 潮流になると, 潮目の形状は波打ち始め明確でなくなり, 減衰・短縮する傾向である，このことから，ごみを集め る強い潮目は西流期に発達することである，これはすで に述べたように, 大阪湾の水塊が播磨灘に流入すること により，潮汐フロントが形成され，それによって生じた 潮目である.この水塊の相違は 12 時近くの潮目を挾む STD 観測から裏付けされた。

（2）潮目は，図-99渦度分布からも示唆されるよ うに, 第 2.3 節で述べた渦度の境界に発達する傾向があ る.このように, 潮目は発散場より渦度場に関係するこ とである。

\section{3 潮目付近の流れ場}

ごみを集める強い潮目の付近の流れを調べるために, 図一11に示すように，木片を人為的に投下し，目視観測 およびGPSによる位置計測し,ごみの取り込み速度を調 ベた.

表一2 潮目付近のごみの取り込み速度

\begin{tabular}{|c|c|c|c|}
\hline 観測值 時刻 & $\begin{array}{c}10: 40 \sim \\
11: 00\end{array}$ & $\begin{array}{c}11: 00 \sim \\
11: 15\end{array}$ & $\begin{array}{c}11: 15 \sim \\
11: 30\end{array}$ \\
\hline ごみの取り込み速度 & & $122 \mathrm{~cm} / \mathrm{s}$ & \\
\hline レータ & $77 \mathrm{~cm} / \mathrm{s}$ & $74 \mathrm{~cm} / \mathrm{s}$ & $38 \mathrm{~cm} / \mathrm{s}$ \\
\hline
\end{tabular}

表一2から, 取り込み速度は同時観測されたレーダ観 測值に比べて, 倍以上大きい.これにより潮目付近のレー ダ空間分解能に比べて狭い範囲で強く吸引する強い速度 場があり，ごみを集める力となっていると推定できる。

\section{6. 潮目の挙動と流れ場の関係}

観測された潮目の挙動を照合データとして，レーダ観 測と潮流の数值計算の流れ場はどちらがより現実の流れ に近いのかを確かめることができる，すなわち，観測さ れた潮目の初期の位置を初期条件として, これらの流れ 場を用いて潮目の数值計算を行い，観測された潮目の挙 動にどのくらい一致するかを調べれば良い，注意すべき ことは，レーダ観測場はすでに示したように限られた海
域であるために，潮目を形成する粒子が観測範囲外に出 る場合がある。その場合はその粒子は消去した。その結 果は図-12に示し，次のことが分かる.

（1）観測された潮目の挙動はレーダ観測場と非常に よく一致するが，潮流数值計算場に対して系統的な相違 が示された。

（2）東流期で，レーダ観測場による潮目の挙動にお いても観測值と必ずしも一致しない。これはすでに述べ たように，東流期で弱い潮目となり，その挙動が明確で なくなったことによる。

以上のことにより，レーダ観測場が潮流数值計算場に 比べて，より正確に実際の表層流を表していると結論で きる.

\section{7. ま と め}

本研究はごみを集める潮目の挙動を明らかにするため に,レーダ観測と潮目目視観測を同時に行い, 次のこと を明らかにした。

（1）レーダ観測された表層流場は，従来の潮流数值 計算結果に比べて，より実際に近いこと.

（2）レーダ観測場と潮流数值計算場の相違は，流速 の分布ばかりでなく，とくに渦度分布において大きい.

（3）ごみを集める潮目は潮汐フロントで形成され, レーダで観測された場の渦度分布と強い相関を有するこ とが推定されること.

今後の課題として，（1）について数値計算との融合を 図ること.（2）と（3）について, 潮目と渦度の分布の 相関を実証し，ごみの集まりやすい海域の予測を試みて いく必要がある。

\section{参 考 文 献}

徳田正幸・久木幸治・大野裕一（1993）：短波海洋レーダによる 流れと波浪の計測, 海岸工学論文集, 第 40 巻, pp. 126-130. 徳田正幸・村上和男・渥美泰彦・永松 宏 (1997)：VHF 沿岸海 洋レーダの開発と流れ観測, 海岸工学論文集, 第 44 巻, pp. 1276-1280.

徳田正幸・永松 宏 (1999)：短波海洋レーダの表層流の自動抽 出法の開発, 海洋調査技術, 第 11 巻, 第 1 号, pp. 1-9. 